\section{Subduction regression of volcanism \\ in New Zealand}

IN discussing the origin of Cenozoic calcalkaline volcanism in northern New Zealand, R. N. Brothers ${ }^{1}$ uses a data base of 'time-lines' constructed from 93 selected $\mathrm{K}-\mathrm{Ar}$ ages. These time-lines are said ${ }^{1}$ to "represent the oldest dated rocks, and thus the initiation of volcanism, at eruptive centres throughout the northern North Island". We will show that this is untrue from which it follows that Brothers' timelines are meaningless.

Brothers' oldest time-lines (in northern Northland) are $21 \mathrm{Myr}$. There is ample published evidence, however, of andesitic and basaltic tuffs and volcaniclastic sandstones in late Oligocene and earliest Miocene ( $\sim 26-22 \mathrm{Myr})$ sedimentary sequences in northern New Zealand (Fig. $1)^{2-4}$, which indicates considerably earlier initiation of volcanism within, or closely adjacent to, Northland, although the exact centres have not been determined.

Younger volcanic centres are identifiable; at least eight early Miocene centres are known in northern New Zealand and Brothers has based his time-lines on dated rocks from seven of them. The published stratigraphic data show clearly that eruptions began in the Middle-Upper Otaian Stage (early Miocene, $\sim 23-21 \mathrm{Myr}$ ) in at least six centres spread along the length of Northland (North Cape, Whangarei Heads, North Coromandel, Waipoua,
Hukatere, Waitakere-Fig. 1). These dates are coincident with the oldest $\mathrm{K}$-Ar dates available from a further two centres (Whangaroa ${ }^{1}$, Tokatoka ${ }^{1}$ ) which presumably also began erupting about the same time.

Brothers ${ }^{1}$ agrees that eruption started at $21 \mathrm{Myr}$ in identified centres in northern Northland, but bases his hypothesis of southward migration of volcanism on a 17-Myr time-line through Waitakere and north Coromandel. The 17-Myr date at Waitakere is taken from pillow lavas interbedded with fossil-dated (mid-Altonian) marine sediments that are high in the volcanic stratigraphic sequence ${ }^{5-7}$ (Fig. 1). The lowest volcanic breccias and lavas exposed at Waitakere are biostratigraphically dated as late Otaian $(\sim 21 \mathrm{Myr})^{5}$, but a number of submarine lahar deposits occurring within flysch around Auckland city are stratigraphically lower than exposed Waitakere rocks ${ }^{4}$. These lahars have features consistent with a western origin $^{3}$ and indicate initiation of volcanism at Waitakere centre in the early half of the Otaian ${ }^{2}(23 \mathrm{Myr})$. A similar submarine lahar deposit occurs within late Otaian flysch $(\sim 21 \mathrm{Myr}), 60 \mathrm{~km}$ south of Auckland ${ }^{4,8}$.

Brothers' 17-Myr time-line links Waitakere with dated plutons at north Coromandel $^{9}$ which intrude the local volcanic sequence which in turn conformably overlies Otaian flysch ${ }^{10}$. Thus initiation of volcanism here is unlikely to have been later than $20 \mathrm{Myr}$. South of Brothers' 11-

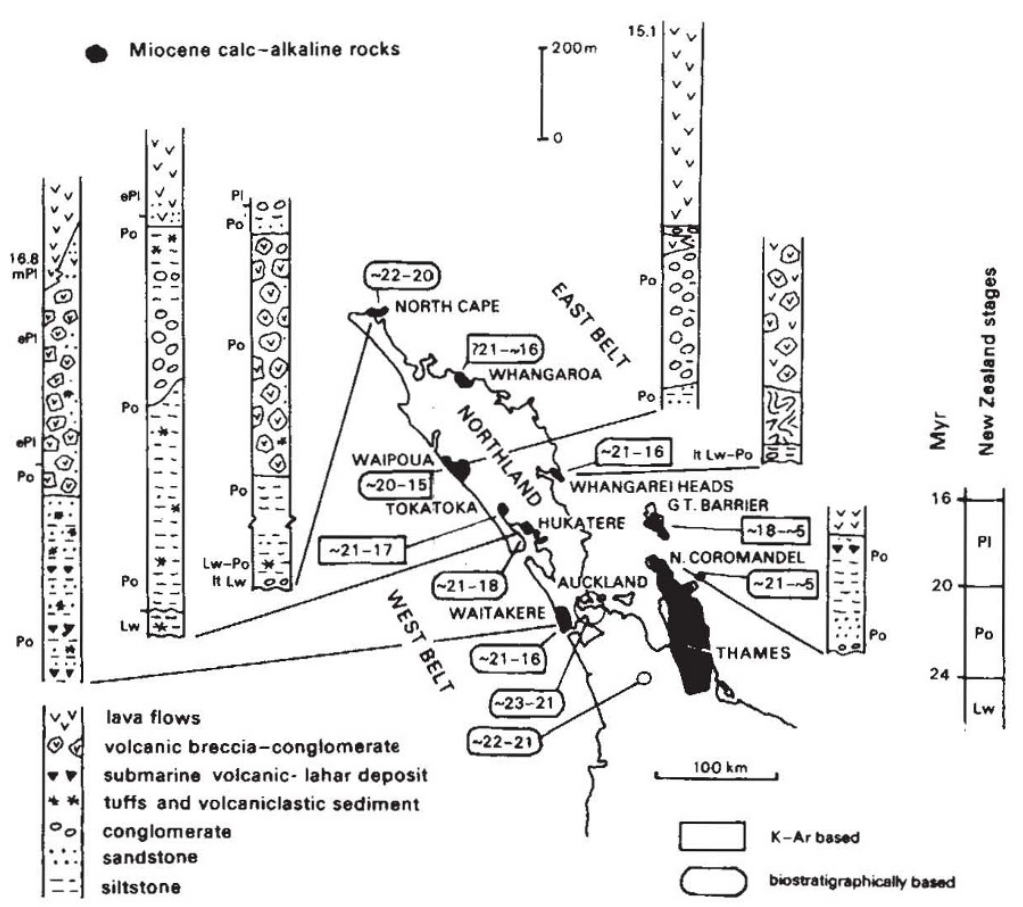

Fig. 1 The northern part of North Island, New Zealand, showing location and age of major centres of early Miocene calc-alkaline eruption. Absolute ages have been determined from a combination of $\mathrm{K}-\mathrm{Ar}$ dates $\mathrm{s}^{1,2}$ and converted biostratigraphic dates based on the International Time Scale model of Berggren ${ }^{14}$ (see right for conversion table from New Zealand stages ${ }^{15}$ ). Generalized columns summarize the stratigraphic evidence for the age of outbreak of volcanism in six areas, with position of biostratigraphic and K-Ar dates shown (North Cape ${ }^{16.17}$, Whangarei Heads $^{18}$, Waipoua ${ }^{2,19}$, Hukatere ${ }^{2.20}$, Waitakere ${ }^{5}$, north Coromandel ${ }^{10,21}$ ). New Zealand Stage symbols: $\mathrm{Lw}=$ Waitakian, $\mathrm{Po}=$ Otaian, $\mathrm{Pl}=$ Altonian

Myr line (Thames), the base of the eastern volcanic pile in Coromandel Peninsula is not exposed ${ }^{11,12}$ and therefore none of the 'time-lines' between $11 \mathrm{Myr}$ and $2 \mathrm{Myr}$ can date the inception of volcanism in this eastern belt.

We have shown: (1) that the published stratigraphy, available to Brothers, indicates near-contemporaneous initiation of major volcanism in two NW-SE belts in northern North Island in the early Miocene (Otaian, 23-21 Myr). This volcanism is calc-alkaline in the younger flows and intrusions ${ }^{13}$, and, although the geochemical character of the older volcaniclastics has not been determined, their petrography and geological setting are identical to the younger rocks. (2) The NE-trending 'time-lines', which form the data-base for Brothers' analysis of Cenozoic subduction and volcanism in northern New Zealand, do not record the earliest volcanism at most of the localities shown and are random lines connecting fortuitously-placed $\mathrm{K}-\mathrm{Ar}$ dates. Therefore a tectonic model based on invalid 'timelines' is itself invalid.

Peter F. BALlance

Department of Geology,

University of Auckland,

Private Bag,

Auckland,

New Zealand

N.Z. Geological Survey,

BRUCE W. HAYWARD

PO Box 30-368

Lower Hutt, New Zealand

FRED J. BROOK

N.Z. Geological Survey,

PO Box 61-012, Otara,

Auckland, New Zealand

1. Brothers, R. N. Nature $309,698-700$ (1984).

2. Hayward, B. W. J. R. Soc. N.Z. 9, 297-320 (1979)

3. Ballance, P. F. J. Geol 82, 439-471 (1974).

4. Ballance, P. F. N. JI Geol Geophys. 19, 897-932 (1976).

4. Ballance, P. F. N.Z. JI Geol. Geophys. 19, 897-932 (1976)

5. Hayward, B. W. N.Z. JI Geol. Geophys. 19,871-895 (1976).
6. Bandy, O., Hornibrook, N. de B. \& Schofield, J. C. N.Z II Geol. Geophys. 13, 980-995 (1970).

7. Hayward, B. W. N.Z. Jl Geol. Geophys. 19, 639-662 (1976).

8. Kear, D. \& Schofield, J. C. Geol, Map N.Z 1:63,360 (Te Kauwhata, Wellington, 1968).

9. Richards, J. R., Cooper, J. A. \& Black, P. M. Nature 211, 725-726 (1966).

10. Skinner D. N. B. Geol. Map N.Z 1:63,360 (Northern Coromandel, Wellington, 1976).

11. Schofield, J. C. Geol. Map N.Z. 1:250,000 Vol. 3 (Wellington, 1967).

12. Healy, J., Schofield, J. C. \& Thompson, B. N. Geoh map N.Z. I: 250,000 Vol. 5 (Wellington, 1974).

13. Wright, A. \& Black, P. M. N.Z. Jl Geol, Geophys. 24, 155-165 (1981).

14. Berggren, W. A. Proc. 6th Int. Working Gp Meeting, IGCP 114, 29-60 (1981).

15. Edwards, A. R. Report N.Z. geol. Surv. 107, 28-32 (1982).

16. Leitch, E. C. Trans. R. Soc. N.Z. Earth Sci. 8, 45-68 (1970).

17. Jenkins, D. G. N.Z geol. Surv. pal. Bull. 42 (1971).

18. Spörli, K. B. \& Isaac, M. Geol. Soc. N.Z. misc. Publ. 30B, 17-18 (1983).

19. Hayward, B. W. Tane 21, 39-47 (1975).

20. Carter, L. R. N.Z. J. Geol. Geophys. 14, 169-191 (1971).

BROTHERS REPLIES-The comments by Ballance $e t$ al. reflect the problems of biostratigraphers trying to equate an imprecise time scale with the more exact ages provided by radiometric methods. The time-lines used in my study ${ }^{1}$ were 